\title{
Сорбция фрерментов на клеточной мембране и субклеточных структурах: механизмы, биологическая роль (обзор)
}

\author{
Башарина О.В., Артюхов В.Г. \\ ФГБОУ ВО «Воронежский государственньй университет», Воронеж
}

Поступила в редакцию 3.06.2019 г.

DOI: 10.17308/sorpchrom.2019.19/1176

Многие клеточные ферменты обратимо связываются с клеточной мембраной и компонентами цитоскелета, сорбция/десорбция является важным механизмом регуляции активности таких ферментов и ферментных систем, а также одним из способов передачи сигнала в клетке. Изучение механизмов адсорбции ферментов позволяет не только регулировать уровень их активности, но и дает возможность управлять внутриклеточной сигнализацией. В качестве примеров рассматриваются некоторые ферменты гликолиза, антиоксидантной системы; как пример ферментов, участвующих в передаче сигнала - NO-синтаза, ряд протеинкиназ.

Изменение локализации ферментов в клетке происходит как из-за изменения параметров внутриклеточной среды, так и в результате ковалентной модификации белка (фосфорилирование, ацилирование и др.). В ряде случаев сорбция на мембране обусловливает повышение локальной концентрации субстрата, что приводит к повышению активности фермента; по-видимому, с этим может быть связана локализация на мембране таких ферментов-антиоксидантов, как СОД и каталаза.

Механизм изменения активности ферментов при их сорбции на мембране может быть обусловлен модификацией микроокружения, конформационной подвижности белка, экранированием активного центра; может изменяться аллостерический механизм регуляции активности фермента. Поскольку все указанные процессы должны быть обратимы, то и сорбция ферментов в этих случаях осуществляется за счет слабых сил - водородных связей, электростатических или гидрофобных взаимодействий.

Многие цитозольные белки выполняют свои функции, находясь в ассоциированном с мембраной состоянии. Их ассоциация с поверхностью мембраны происходит с помощью структурных белковых модулей (доменов), имеющих специфичность к тем или иным липидам. Цитозольные белки-эффекторы обладают структурными доменами, способными связываться с фосфоинозитидами мембранной поверхности. В связанном с мембранами состоянии белки-эффекторы находятся, в основном, в комплексе с фосфоинозитид-специфичными киназами и фосфатазами, а также с малыми GTP-азами, что необходимо для адресной ассоциации белков-эффекторов с мембранами органелл.

Ключевые слова: ферменты, сорбция на мембране, адсорбционный механизм регуляции активности, передача сигнала в клетку

\section{Sorption of enzymes on the cell membrane and subcellular structures: mechanisms, biological role (Review)}

\author{
Basharina O.V., Artyukhov V.G. \\ Voronezh state University, Voronezh
}

Many cellular enzymes reversibly bind to the cell membrane and cytoskeleton components, sorption/desorption is an important mechanism for regulating the activity of such enzymes and enzyme systems, 
as well as one of the ways of signal transmission in the cell. The study of the mechanisms of enzyme adsorption allows not only to regulate the level of their activity, but also makes it possible to control intracellular signaling. As examples, some enzymes of glycolysis, antioxidant system are considered; as an example of enzymes involved in signal transmission - NO-synthase, a number of protein kinases.

Changes in the localization of enzymes in the cell occurs both due to changes in the parameters of the intracellular medium, and as a result of covalent protein modification (phosphorylation, acylation, etc.). In some cases, sorption on the membrane causes an increase in the local concentration of the substrate, which leads to an increase in the activity of the enzyme; apparently, this may be associated with the localization on the membrane of such antioxidant enzymes as SOD and catalase.

The mechanism of change in enzyme activity during their sorption on the membrane can be due to changes in the microenvironment, conformational mobility of the protein, screening of the active center; the allosteric mechanism of regulation of enzyme activity can change. Since all these processes must be reversible, the sorption of enzymes in these cases is carried out due to weak force - hydrogen bonds, electrostatic or hydrophobic interactions.

Many cytosolic proteins perform their functions in the membrane-associated state. Their association with the surface of the membrane occurs with the help of structural protein modules (domains) that have specificity to certain lipids. Cytosolic effector proteins have structural domains that can bind to the phosphoinositides of the membrane surface. In the association with membranes the proteins-effectors are mostly in a complex with phosphoinositide-specific kinases and phosphatases, and small GTPases what is necessary for address association protein effectors with membranes of organelles.

Keywords: enzymes, membrane sorption, adsorption mechanism of activity regulation, signal transmission to the cell

\section{Введение}

В настоящее время наряду с "классической" энзимологией, рассматривающей ферментные системы как относительно гомогенные фазы, выделилось направление, учитывающее особенности пространственной и структурной организации ферментных систем. В рамках этого направления разработаны различные методические подходы для решения проблемы надмолекулярной организации и регуляции метаболических процессов в клетке $[1,3]$.

Адсорбционный механизм регулирования активности ферментов и ферментных комплексов реализуется при соблюдении следующих условий: 1) существует обратимое равновесие между цитоплазматической и адсорбированной формой фермента; 2) при адсорбции изменяются каталитические характеристики ферментативной реакции; 3) обратимое равновесие между свободной и связанной формами фермента регулируется с помощью клеточных метаболитов или при изменении физикохимических параметров микроокружения фермента [2]. В энзимологии в настоящее время первоочередной задачей является изучение каталитических свойств ферментов в составе сложных, в том числе мультиэнзимных, комплексов клетки [3].

Развитие энзимологии в XXI веке касается разработки нового направления надмолекулярной регуляции свойств ферментов, связанных с мембранными структурами клеток $[4,5]$.

Физиологическая важность обратимого связывания ферментов субклеточными структурами состоит, прежде всего, в том, что адсорбция ферментов может приводить к изменению их каталитических и регуляторных свойств и, следовательно, является фактором, регулирующим активность ферментов. Кроме того, именно адсорбция ферментов обеспечивает их компартментализацию. Адсорбированные ферменты способны образовывать упорядоченные мультиферментные структуры (метаболоны), благодаря чему появляется возможность регулировать метаболический процесс как единое целое. В ряде случаев сорбция/десорбция фермента на мембране является способом внутриклеточной сигнализации. 


\section{Адсорбция ферментов как способ регуляции их активности}

Биомембраны играют важную роль в функционировании целого ряда белков. После разрушения клетки многие ферменты можно обнаружить и в растворимой, и в мембранной фракциях. Такие ферменты, как правило, являются периферическими белками мембраны, в зависимости от физиологического состояния клетки они локализуются либо на мембране, либо в цитозоле. Некоторые их этих ферментов катализируют реакции с участием мембраносвязанных субстратов, для функционирования такие белки должны быть способны хотя бы временно связываться с мембраной, которая создает среду, в которой липофильные субстраты могут быть превращены в соответствующие продукты.

Мембрана определяет локализацию фермента или группы ферментов, компоненты мембраны при этом могут осуществлять аллостерическую регуляцию ферментов. Так, например, липоксигеназы относятся к ферментам, осуществляющим реакции пероксидного окисления липидов. Большинство липоксигеназ - цитозольные ферменты с аффинностью к мембранам. Транслокация фермента из цитозоля на мембранную поверхность является одной из стадий регуляции уровня продуктов липоксигеназного катализа в клетке. Сорбция на мембранной поверхности описана для большинства липоксигеназ растительного и животного происхождения. В обзоре [6] представлены данные по регуляции активности этих ферментов природными и химически модифицированными соединениями липидной природы. Возможность липидов регулировать липоксигеназную активность может осуществляться через: белок-липидные взаимодействия одного из доменов фермента с мембраной, изменение аффинности фермента, аллостерическую регуляцию, селективность к типу субстрата. Регуляторное влияние сорбции липоксигеназы на мембране на ферментативную активность зависит от уровня липофильности эффекторов.

Активация 5-липоксигеназы (5-LO) включает в себя ее кальцийзависимую транслокацию в ядерную оболочку, где она катализирует двухступенчатую трансформацию арахидоновой кислоты в лейкотриен А. Были изучены мембрансвязывающие свойства N-концевого домена 5-LO, который имеет структуру, подобную мембрансвязывающему домену в протеинкиназе C [7]. Этот $\mathrm{Ca}^{2+}$-зависимый домен селективно связывает цвиттер-ионы фосфатидилхолина с участием трех остатков триптофана, расположенных в $\mathrm{Ca}^{2+}$-связывающей петле. Регуляция связывания с мембраной этого домена осуществляется двумя способами: локальной нейтрализацией анионной поверхности белка и изменением ориентации алифатических и ароматических боковых цепей аминокислотных остатков в $\mathrm{Ca}^{2+}$-связывающей петле, что приводит к встраиванию белка в мембрану и гидрофобному взаимодействию с липидами [6-8]. Таким образом, при объяснении липоксигеназного катализа необходимо учитывать влияние микроокружения фермента.

В работе [9] предлагается кластеро-кинетическая гипотеза ферментативного катализа: кинетический энзимокластер рассматривается как динамическое объединение нескольких гомо- (гетеро-) конформеров фермента, образующееся в процессе катализа, которое может рассматриваться как самостоятельная единица. Предполагается, что для любых ферментов как минимум существуют два основных ферментативных конформера: каталитический и агрегационный. Каталитический конформер характеризуется тем, что при объединении субъединиц в единое целое все активные центры фермента остаются активными; агрегационный конформер имеет такую структуру, при которой часть активных центров фермента экранируется. В целом, каждый энзимокластер представлен взаимодействием различного отношения каталитических и агрегационных конформеров между собой. Авторы делают заключе-

Бамарина и др. / Сорбционные и хроматографические процессы. 2019. Т. 19. № 5 
ние, что изменение микроокружения ферментов, в частности оксидоредуктаз (алкогольдегидрогеназы, лактатдегидрогеназы), приводит к трансформации их конформеров (каталитических и агрегационных).

В растворах чувствительными к вязкости и лимитирующими скорость реакции являются не процессы диффузии реагентов, а сам процесс катализа на стадиях активации субстрата и высвобождения продукта реакции [10]. Эти стадии связаны с конформационными перестройками домена активного центра фермента. Причем, чем больше подвижность домена с активным центром фермента зависит от вязкости среды, тем больше вязкость среды влияет на активность фермента и, следовательно, на скорость реакции [11].

Метаболизм можно представить как систему скоординированных в пространстве и времени физико-химических превращений веществ, которые обеспечиваются различными перемещениями молекулярных компонентов этой системы [12]. Осуществляться пространственно-временная координация движения молекул и скоростей биохимических реакций может разными способами. Один из них - компартментализация, которая, в свою очередь, может реализовываться за счет мембранных образований, либо надмолекулярных комплексов [13], например, метаболоны ферментов цикла трикарбоновых кислот [14] и гликолиза [15]. В ходе компартментализации происходит адсорбция ферментов (или их комплексов) на мембранных структурах клетки или на компонентах цитоскелета.

Показано, что гликолитические ферменты, в частности, глицеральдегид-3фосфатдегидрогеназа (GAPDH), альдолаза, фосфофруктокиназа, лактатдегидрогеназа (ЛДГ) и пируваткиназа объединяются в мультиэнзимные комплексы на внутренней поверхности мембраны эритроцитов человека $[16,17]$. В основном связывание этих ферментов происходит за счет водородных связей и электростатических взаимодействий с белком полосы 3 эритроцитарной мембраны. Для выявления мембранных белков, участвующих в сборке гликолитического метаболона, с помощью метода конфокальной микроскопии были исследованы эритроциты мышей, нокаутированных по генам основных мембранных белков эритроцитов [18]. Ферменты гликолиза мышей, нокаутированных по белку полосы 3, не были связаны с мембраной, а распределялись по всей цитоплазме независимо от состояния оксигенации эритроцитов. Напротив, в эритроцитах мышей, лишенных $\alpha$-спектрина, анкирина, белка 4.2, белка 4.1, $\beta$-аддуцина, исследуемые ферменты были адсорбированы на мембране. Поскольку сборка этих комплексов чувствительна к физиологическим стимулам, таким как фосфорилирование белка полосы 3 и дезоксигенация гемоглобина (при дезоксигенации отмечен сдвиг равновесия в сторону цитоплазматических форм ферментов), было высказано предположение, что регулирование сборки гликолитического метаболона может быть важным этапом в регуляции метаболизма глюкозы. Так, было замечено, что ассоциация комплексов на мембране коррелирует со сдвигом метаболизма глюкозы от гликолиза к пентозофосфатному пути $[17,19]$. Предложены последовательности аминокислот белка полосы 3 , участвующие в связывании некоторых ферментов гликолиза (альдолазы, GAPDH, фосфофруктокиназы), эти последовательности обогащены глутаминовой кислотой, содержат тирозин [19].

В работе [20] исследованы особенности внутриклеточной локализации двух эритроцитарных ферментов: ЛДГ и альдегиддегидрогеназы (АлДГ, фермент биотрансформации ксенобиотиков альдегидной природы). Оба фермента взаимодействуют с мембраной эритроцитов, что позволяет рассматривать возможность их мембранной регуляции при различных состояниях организма. На основании проведенных кинетических исследований делается заключение, что ЛДГ и АлДГ эритроцитов взаимодействуют не только с мембраной, но и функционально связаны друг с дру- 
гом общим коферментом - НАД, характер данного взаимодействия зависит от физико-химического состояния клеточной мембраны. Если целостность мембраны сохранена, то АлДГ оказывает ингибирующее влияние на активность лактатдегидрогеназы, если же мембрана эритроцитов повреждена, что имеет место в условиях окислительного стресса [21], то изменяются ее физико-химические свойства; в результате такой перестройки мембраны характер функционального взаимодействия ферментов друг с другом нарушается. В итоге ЛДГ оказывает ингибирующее воздействие на АлДГ.

Структурно-функциональные перестройки мембран сопровождаются изменением пула белков, связанных с мембраной (как интегральных, так и периферических). Так, например, у пациентов с артериальной гипертензией выявлена связь между показателем сфероцитарности и белками мембраны эритроцитов ( $\beta$-спектрином, тропомиозином, глицеральдегид-3-фосфат-дегидрогеназой, анион-транспортным белком) [22].

На адсорбцию белков на мембране влияет как состав интегральных белков мембраны, так и особенности ее липидного состава. Так, например, в работе [23] авторы использовали метод флуоресцентных зондов (на примере 1-анилинонафталин8-сульфоната) для установления компонентов липидного бислоя, необходимых для связывания белка M1 с мембраной, а также выяснения возможной ориентации белка относительно липидной мембраны. Было установлено, что для адсорбции матриксного белка M1 (матриксный белок M1 формирует каркас вируса гриппа) липидный бислой должен содержать в своем составе фосфатидилсерины, в то время как холестерин и фосфатидилэтаноламин в незаряженной мембране не способствуют связыванию белка. Кроме того, полученные данные позволяют предположить, что белок M1, связываясь положительно заряженными аминокислотами с отрицательно заряженным липидным бислоем, экспонирует наружу анионные участки.

Имеются данные о том, что изменения активности мембрансвязанных ферментов лимфоцитов, в частности, аденозиндезаминазы и 5'-нуклеотидазы, могут влиять на формирование и регуляцию иммунного ответа организма $[24,25]$. Указанные ферменты являются липидзависимыми, их активность в значительной степени опосредована структурными изменениями мембран, которые имеют место в условиях окислительного стресса. Определение изменений активности указанных ферментов в лимфоцитах важно как для изучения одного из вероятных патогенетических механизмов иммуносупрессии, так и для выяснения молекулярных механизмов сорбции ферментов на мембране [25].

Другим важным ферментом, активность которого определяется связыванием с мембранными структурами, является эндотелиальная NO-синтаза (eNOS). Эта форма NO-синтазы подвергается миристоилированию и пальмитоилированию, которые определяют его внутриклеточную локализацию и влияют на активность данного фермента [26]. Установлено, что мутация сайта $\mathrm{N}$-миристоилирования превращает эндотелиальную NO-синтазу из мембранного белка в цитозольный, в растворимой форме фермент обладает более низкой активностью [27]. Для активации этой изоформы фермента необходим кальмодулин, но в регуляции активности eNOS могут участвовать и другие белки, в частности кавеолин-1 [28]. Кавеолины являются структурообразующими элементами кавеол - выпуклостей цитоплазматической мембраны клеток, которые играют важную роль в функционировании и пространственной организации большого числа макромолекул, ответственных за передачу биохимической информации. Кавеолины взаимодействуют с различными сигнальными молекулами в каскадах, в том числе с эндотелиальной NO-синтазой (eNOS). Количество кавеолина находится в обратной зависимости от продукции NO eNOS. 
Связывание кавеолина-1 с оксигеназным доменом eNOS нарушает взаимодействие последнего с кальмодулином, в результате фермент становится неактивным [29]. Предположительно, данный механизм представляет собой отрицательную обратную связь между количеством оксида азота и активностью еNOS, т.к. в ответ на увеличение концентрации NO увеличивается активность протеинкиназы Src, активирующей кавеолин-1 путем фосфорилирования и повышающей тем самым его сродство к eNOS [30]. Таким образом, связывание кавеолина1 с оксигеназным доменом eNOS может предотвращать инактивацию данного фермента, поэтому кавеолин-1 представляется перспективной потенциальной мишенью для «приложения» агентов, модулирующих активность eNOS.

Известно, что в клетках крови антиоксидантные ферменты, в частности, супероксиддисмутаза (СОД) и каталаза, оказывают защитное действие на плазматическую мембрану $[31,32]$, причем степень защитного эффекта от окислительного фотоиндуцированного стресса зависит от условий инкубации данных ферментов с клетками. Так, повышение активности $\mathrm{Ca}^{2+}$-АТФазы в мембранах УФ-облученных лимфоцитов в присутствии СОД указывает на то, что в клетках СОД оказывает защитное действие на плазматическую мембрану, и, следовательно, снижение активности $\mathrm{Ca}^{2+}$-АТФазы в среде без антиоксидантов обусловлено (хотя бы отчасти) повышением пероксидного фотоокисления липидов. Установлено, что применение антиоксидантов наиболее эффективно при их внесении в среду за 20 мин до облучения, так как их фотопротекторные свойства зависят не только от присутствия в растворе, но и от взаимодействия с мембраной [33]. Выявлено увеличение защитного действия СОД по отношению к эритроцитарной мембране при внесении антиоксиданта перед облучением. Тот факт, что фотопротекторные свойства СОД проявляются в большей степени в том случае, если воздействию УФ-света предшествовала инкубация эритроцитарных клеток с ферментом, можно рассматривать как косвенное доказательство того, что в эритроцитах СОД может быть локализована на мембране [34]. .В наших работах было показано, что активность СОД и каталазы в эритроцитарных мембранах зависит от условий гемолиза клеток - при использовании в качестве гемолитика фосфатного буфера (pH 7.4, 0.05 моль/дм ${ }^{3}$ ) активность СОД значительно выше, чем в случае гемолиза водой. Эти данные указывают на то, что и СОД, и каталаза могут обратимо связываться с клеточной мембраной. Возможно, имеет место адсорбционный механизм регуляции активности фермента. В пользу этого предположения говорит тот факт, что степень активации сорбированной на мембране СОД снижается при сдвиге $\mathrm{pH}$ в щелочную сторону (от 5.0 до 8.4). Возможно, изменение заряда мембраны приводит к десорбции СОД с поверхности, следовательно, связывание фермента с мембраной осуществляется за счет электростатических взаимодействий. Это подтверждается также изменением характеристик спектра флуоресценции мембранного зонда АНС-8 в тройном комплексе АНС - СОД - мембрана клетки[34].

\section{Адсорбция ферментов на мембране как способ внутриклеточной сигнализации}

Изменение компартментализации белковой молекулы в клетке, например, при ее переходе из цитоплазмы на мембрану, может быть причиной изменений свойств белков, существенных для их сигнальных функций. В связывании периферических белков с мембраной принимают участие домены, имеющие специфичность к определенным липидам.

Бамарина и др. / Сорбционные и хроматографические процессы. 2019. Т. 19. № 5 
Динамическая ассоциация многих белков, в том числе и ряда протеинкиназ, со специфическими внутриклеточными компартментами - один из способов регуляции их активности. Яркий пример такого рода - протеинкиназа С (РКС). Это ключевой фермент системы передачи сигнала, запускаемого быстрым расщеплением фосфатидилинозитолов в плазматической мембране.

Протеинкиназа С является мономером и имеет двухдоменную структуру. Регуляторный домен $\mathrm{C} 1$ (N-концевой домен), присутствующий во всех изоформах PKC, имеет сайт связывания с диацилглицеролом, а также с его негидролизуемыми, нефизиологическими аналогами - форболовыми эфирами, которые являются промоторами опухолевого роста. Домен С2 связывается с $\mathrm{Ca}^{2+}$ и присутствует как в классических, так и в новых изоформах, но функционирует только в классических РКС [35]. Псевдосубстратная область, которая присутствует во всех изоформах РКС, представляет собой небольшую последовательность аминокислот, которые имитируют субстрат и связывают субстрат-связывающую полость в каталитическом домене, поддерживая неактивное состояние фермента. Когда ионы кальция и диацилглицерол присутствуют в достаточной концентрации, они связываются с доменами С2 и C1 соответственно и способствуют адсорбции РКС на мембране. Это взаимодействие с мембраной приводит к высвобождению псевдосубстрата из каталитического сайта и активации фермента [36].

Домен С2 фермента РКС связывает от двух до трех ионов $\mathrm{Ca}^{2+}$, что способствует его связыванию с фосфатидилсерином - компонентом клеточной мембраны. Прикрепление PKC к мембране происходит в области $\beta$-структуры участка С2 фермента, при этом $\beta$-структура располагается параллельно поверхности клеточной мембраны [37, 38]. Характерной особенностью новых РКС является отсутствие соответствующих остатков, способных сформировать сайт связывания $\mathrm{Ca}^{2+}$. При этом регуляция активности и связывания РКС с мембраной может осуществляется посредством фосфорилирования различных аминокислотных остатков как каталитического, так и регуляторного доменов протеинкиназы C [39-45]. Так, например, установлено, что фосфорилирование остатка Туr90 регуляторного домена РКС $\theta$ может модулировать ее активность [43]. Исследования, проведенные с применением рентгеноструктурного анализа, показывают, что состав клеточной мембраны влияет на характер связывания с ней РКС и, соответственно, на активность фермента [44, 45].

В работе [46] обсуждается участие одной из форм РКС - PКС $\zeta$ - в перестройках актинового цитоскелета путем взаимодействия с миотилином. Миотилин это саркомерный белок с двумя Ig-подобными доменами, он может непосредственно связывать F-актин и $\alpha$-актин, предотвращая разборку филаментов. Перестройка актинового цитоскелета важна для объединения транспортера глюкозы GLUT4, фосфатидилинозитол-3-киназы и связанного с везикулами мембранного белка VAMP-2, необходимого для поглощения глюкозы $[47,48]$.

Протеинкиназа В (PKB, также известная как Akt) включает три близкие изоформы - PKBa/ $/ / \gamma$ (или Akt1, Akt2 и Akt3 соответственно) [49]. РКВ, как и РКС, является важным компонентом фосфатидилинозитол-3-киназного (PI3K) сигнального пути, она имеет множество субстратов и способствует передаче сигнала по этому пути. Большую часть времени РКВ находится в цитоплазме клетки в неактивном состоянии. При активации РІ3К-сигнального пути в клетке синтезируется вторичный мессенджер фосфатидилинозитол-3-фосфат, в результате непосредственного связывания фосфатидилинозитол-3-фосфата с доменом, гомологичным плекстрину, РКВ может быть активирована и транслоцирована к плазматической мембране [50].

Пространственно-временное распределение фосфоинозитидов в клетке создает систему реперов (маяков), управляющих клеточными процессами, и роль меха- 
низма управления играет адресная адсорбция цитозольных белков с локальными сайтами фосфоинозитидов, расположенными на поверхности клеточных мембран [51]. Почему именно фосфоинозитидам отводится столь важная роль? Многозарядность (до -4 при рН 7.0) и низкое, относительно других липидов, содержание позволяют фосфоинозитидам формировать локальные сайты (рафты) с большим отрицательным зарядом на мембранной поверхности, что дает им преимущество во взаимодействии с положительно заряженными белковыми группами. Например, содержание фосфатидилинозитол-4,5-бисфосфата составляет примерно около $1 \%$ от общей массы фосфолипидов в мембране [52]. Динамичный контроль содержания фосфоинозитидов в мембранах, осуществляющийся с помощью фосфоинозитидспецифичных киназ и фосфатаз, дает возможность клетке гибко реагировать на сигналы $[51,53]$.

В настоящее время описана структура более 10 видов белковых доменов, специфичных к различным формам фосфоинозитидов; эти домены обозначают как РН, PX (Phox), FYVE, ANTH и другие $[35,51,54]$. Одним из наиболее изученных и часто встречающихся является плекстринподобный домен (pleckstrin-homology domain, РН). Он представляет собой домен, включающий в себя около 120 аминокислот, и присутствует во многих белках, участвующих во внутриклеточной сигнализации или являющимися компонентами цитоскелета [55-58]. Этот домен может связываться с фосфатидилинозитолами в биологических мембранах (например, с фосфатидилинозитол-(3,4,5)-трифосфатом и фосфатидилинозитол-(4,5)-дифосфатом) [59] и с рядом белков, таких как $\beta \gamma$-субъединицы гетеротримерных G-белков [60] и протеинкиназы C [61]. С помощью этих взаимодействий РН-домены играют важную роль в связывании белков с клеточными мембранами, направляя их к соответствующим клеточным компартментам.

РН-домены содержат участки, богатые остатками лизина и аргинина, которые могут создавать электростатические контакты с отрицательно заряженными группами липидов мембранной поверхности [62]. Пространственная структура и высокий положительный потенциал этих последовательностей способствуют специфичному связыванию РН-доменов с фосфоинозитидами, но возможны и неспецифичные взаимодействия с другими липидами [62, 63].

Однако не все сигнальные белки, участвующие в фосфоинозитодном пути передачи сигнала, имеют специфические домены. Еще один представитель регуляторных протеинкиназ - протеинкиназа MAK-V - относится к группе АМРК-подобных протеинкиназ (5'AMФ-активируемая протеинкиназа, AMP activated protein kinase) и является единственным представителем своей подгруппы [64]. Ассоциация MAK-V со специфическими внутриклеточными компартментами, подобно другим протеинкиназам, может быть существенным фактором для ее функционирования. Протеинкиназа MAK-V была изначально идентифицирована в результате сравнительных анализов опухолей с различными свойствами [65]. С помощью иммунофлуоресцентного анализа установлено, что значительная часть белка MAK-V в клетке ассоциирована с мембранами, причем предполагается эволюционная консервативность механизма локализации MAK-V на мембране [66]. Анализ аминокислотной последовательности MAK-V не выявил сайтов ковалентных модификаций, которые определяют ассоциацию белков с мембранами за счет гидрофобных взаимодействий (таких как миристилирование, пальмитоилирование или пренилирование). Партнерами по взаимодействию MAK-V с компонентами мембраны могут быть эволюционно консервативные ассоциированные с мембранами белки или молекулы небелковой природы. К последним относятся фосфатидилинозитолфосфаты, являющиеся мембранным интерфейсом взаимодействия с различными белками [35-40, 67-70]. Как показал 
анализ первичной структуры, белок MAK-V лишен известных фософатидилинозитол-связывающих доменов. Однако каталитический домен MAK-V содержит богатую положительно заряженными аминокислотными остатками последовательность. Принимая во внимание консервативность Lys/Arg-богатой последовательности в протеинкиназах MAK-V человека, мыши, лягушки и рыбы, можно предположить, что именно она опосредует взаимодействие MAK-V с фосфатидилинозитолфосфатом, тем самым определяя ассоциацию протеинкиназы с мембраной. Таким образом, авторы работы [66] предлагают возможный механизм ассоциации данного фермента с внутриклеточными мембранами: мембранная локализация MAK-V определяется областью, включающей в себя каталитический и убиквитин-ассоциированный домены.

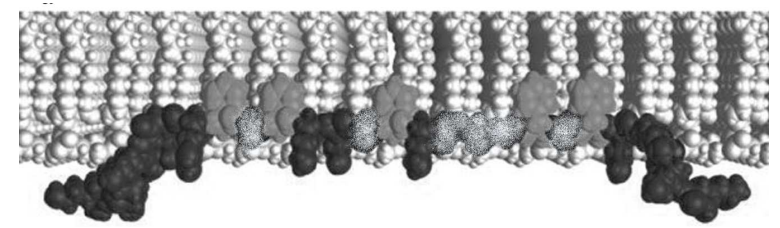

a

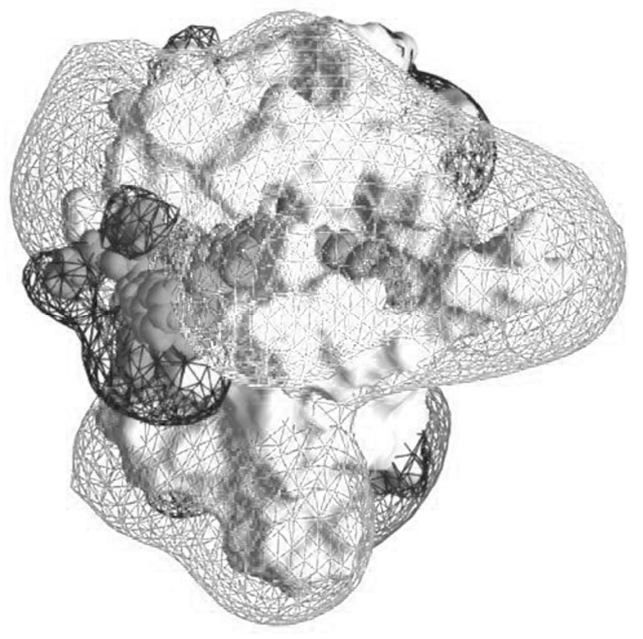

6

Рис. 1. Взаимодействие эффекторного домена белка-субстрата протеинкиназы С с мембраной (а) и кальмодулином (б) $[52,71]$.

Белки-субстраты протеинкиназы C (calmodulin-binding domain of myristoylated alanine-rich C kinase substrate - MARCKS) играют важную роль в поддержании формы клеток, способности к движению, секреции, трансмембранном транспорте, регуляции клеточного цикла и других важных клеточных процессов. MARCKS связаны $\mathrm{N}$-концом с липидами мембраны через миристоленовую кислоту, их связывание с мембраной регулируется ионами $\mathrm{Ca}^{2+}$, кальмодулином, протеинкиназой С. Кальмодулинсвязывающий домен MARCKS взаимодействует с различными целевыми молекулами, включая кальмодулин, актин и липиды мембраны, этот белок функционирует как «точка пересечения» нескольких путей передачи сигнала [52] (рис 1). На рисунке представлены: а) модель основной части эффекторного домена (151-175 аминокислотные остатки бычьего MARCKS), наложенная на модель липидного бислоя мембраны; эта модель иллюстрируюет его экспериментально определенную вытянутую конформацию и расположение пяти гидрофобных (обозначены серым цветом) и 13 основных (черных) остатков; б) кристаллическая структура комплекса основной части эффекторного домена в комплексе с $\mathrm{Ca}^{2+}$-кальмодулином [71]. Электростатические эквипотенциальные профили показаны в виде светлых $(-25 \mathrm{mV})$ и черных (+25 mV) сеток. Высокий отрицательный заряд комплекса данного белка с кальмодулином будет отталкивать его от отрицательно заряженной цитоплазматической части клеточной мембраны. 


\section{Заключение}

Таким образом, адсорбция ферментов на мембране является важнейшим внутриклеточным процессом, роль которого состоит в регуляции активности ферментов, в компартментализации внутриклеточных процессов, а также в участии ферментов в передаче сигнала.

Изменение локализации ферментов в клетке происходит как из-за изменения параметров внутриклеточной среды, так и в результате ковалентной модификации белка (фосфорилирование, ацилирование и др.). В ряде случаев сорбция на мембране обусловливает повышение локальной концентрации субстрата, что приводит к повышению активности фермента; по-видимому, с этим может быть связана локализация на мембране таких ферментов-антиоксидантов, как СОД и каталаза.

Механизм изменения активности ферментов при их сорбции на мембране может быть обусловлен изменением микроокружения, конформационной подвижности белка, экранированием активного центра, может изменяться аллостерический механизм регуляции активности фермента.

Поскольку все указанные процессы должны быть обратимы, то и сорбция ферментов в этих случаях осуществляется за счет слабых сил - водородных связей, электростатических или гидрофобных взаимодействий. Сорбция ферментов в клетке зависит как от белкового, так и от особенностей липидного состава мембраны. Способность белка локализоваться на мембране должна обусловливаться детерминантами в составе полипептидной цепи, обеспечивающими привлечение белка на мембрану.

Многие цитозольные белки выполняют свои функции, находясь в ассоциированном с мембраной состоянии. Их ассоциация с поверхностью мембраны происходит с помощью структурных белковых модулей (доменов), имеющих специфичность к тем или иным липидам. Цитозольные белки-эффекторы обладают структурными доменами, способными связываться с фосфоинозитидами мембранной поверхности.

\section{Список литературы/References}

1. Artyukhov V.G., Basharina O.V., Molekuljarnaja biofizika: mehanizmy protekanija i reguljacii vnutrikletochnyh processov, Voronezh, VGU Publ., 2012, 220 p.

2. Artyukhov V.G., Nakvasina M.A., Strukturno-funkcional'noe sostojanie biomembran i mezhkletochnye vzaimodejstvija, Voronezh, VGU Publ., 2008, 156 p.

3. Roos G., Geerlings P., Messens J., J. Phys. Chem. B., 2009, Vol. 113, pp. 13465-13475.

4. Franco T., Low P.S., Transfus Clin Biol., 2010, Vol. 17, No 3, pp. 87-94.

5. Yong Keun Park, Catherine A.B., Thorsten A., Nir S.G. et al., PNAS, 2010, Vol. 107, No 4, pp. 1289-1294.

6. Skatertna T.D., Kopich V.M., Kharitonenko G.I., Kharchenko O.V., Biopolymers and Cell., 2015, Vol. 31, No 3, pp. 161-173.

7. Kulkarni S, Das S, Funk CD, Murray D. et al., J Biol Chem., 2002, Vol. 277, No 15, pp 13167-13174.
8. Pande AH, Qin S, Tatulian SA., Biophys J., 2005, Vol. 88, No 6, pp. 4084-4094.

9. Zimin Ju.V., Ulanova A.A., Solov'eva A.G., Fundamental'nye issledovanija, 2012, No 9, pp. 559-562.

10. Puchkov E.O., Biol. Membrany, 2014, Vol. 31, No 1, pp. 3-13.

11. Barbier G.G., Campbell W.H., J. Biol. Chem., 2005, Vol. 280, No 28, pp. 2604926054.

12. Wheatley D., J. Exp. Biol., 2003, Vol. 206, No 12, pp. 1955-1961.

13. Kurganov B.I., Lyubarev A.E., Biokhimiya, 1989, Vol. 54, No 5, pp. 716-718.

14. Lyubarev A.E., Kurganov B.I., Molekulyar. Biologiya, 1987, Vol. 21, No 5, pp. 12861296.

15. Kurganov B.I., Lyubarev A.E., Molekulyar. Biologiya, 1988, Vol. 22, No 6, pp. 16051613. 
16. Messana I, Orlando M, Cassiano L. Pennacchietti L. et al., FEBS Lett., 1996, Vol. 390, No 1, pp. 25-28.

17. Campanella M.E., Chu H., Low P.S., PNAS, 2005, Vol. 102, No 7, pp. 2402-2407.

18. Campanella M.E., Chu H., Wandersee N.J., Peters L.L. et al., BLOOD, 2008, Vol. 112, No 9 , pp. 3900-3906.

19. Chu H, Low P.S., Biochem J., 2006; Vol. 400, No 3, pp.143-151.

20. Zimin Ju.V., Solov'eva A.G., Fundamental'nye issledovaniya, 2012, No 12, pp. 59-61.

21.Olszewska M., Wiatrow J., Bober J., Stachowska E.F. et al., Postepy Hig Med Dosw., 2012, No 66, pp. 534-542.

22. Anikienko I.V., Pivovarov Yu.I., Sergeeva A.S., Borovskij G.B, Biol. Membrany, 2019, Vol. 36, No 2, pp. 137-146.

23. Shilova L.A., Knjazev D.G., Fedorova N.V., Shtykova Je.V. et al., Biol. Membrany, 2017, Vol. 34, No 3, pp. 194-200.

24. Tapbergenov S.O., Tapbergenov T.S., Biomedicinskaya khimija, 2005, Vol. 51, No 2, pp. 199-205.

25. Moskvichjov E.P., Rozhkovskij Ya.V., Svit medicini ta biologii, 2014, Vol. 10, No 3, pp. 129-133.

26. Marsden P.A., Heng, H.H.Q., Scherer S.W., Stewart R.J. et al., J. Biol. Chem., 1993, Vol. 268, pp. 17478-17488.

27. Sakoda T., Hirata K., Kuroda R., Miki N. et al., Mol. Cell. Biochem., 1995, Vol. 152, No 2, pp. 143-148.

28. Sbaa E., DeWever J., Martinive Ph., Bouzin C. et al., Circ. Res., 2006, Vol. 98, pp. 12191227.

DOI:

10.1161/01.RES.0000220648.80170.8b

29. Sharma A., Yu C., Bernatchez P.N., Can. J. Cardiol., 2010, Vol. 26 (Suppl. A), pp. 5-8.

30. Chen Z., Bakhshi F.R., Shajahan A.N., Sharma T. et al., Mol. Biol. Cell., 2012, Vol. 23, No 7, pp. 1388-1398.

31. Verbolovich V. P., Podgornyj Yu.K., Podgornaja L.M., Biol. Nauki, 1989, No 1, pp. 2733.

32. Basharina O.V., Zemchenkova O.V., Artyukhov V.G., Radiacionnaja biologija. Radiojekologija, 2012, Vol. 52, No 6. pp. 602-607.

33. Zemchenkova O.V., Artyukhov V.G., Basharina O.V., Pozdnjakova S.I. et al., Vestnik VGU. Serija: Khimija, Biologija, Farmacija, 2011, Vol. 2, pp. 92-96.

34. Artyukhov V.G., Basharina O.V., Vashanov G.A., Nakvasina M.A. et al., Oligomernye belki: strukturno-funkcional'nye modifikacyi $i$ rol' sub'edinichnyh kontaktov, Voronezh, VGU Publ., 1997, 264 p.

35. Lemmon M.A., Nat. Rev. Mol. Cell Biol., 2008, Vol. 9, pp. 99-111.

36. Nishizuka Y., FASEB Journal., 1995, Vol. 9, No 7, pp. 484-496. DOI:10.1096/FASEBJ.9.7.7737456. PMID 7737456

37. Freeley M., Kelleher D., Long A., Cell Signal., 2011, Vol. 23, pp. 753-762.

38. Kheifets V., Mochly-Rosen D., Pharm. Res., 2007, Vol. 55, pp. 467-476.

39. Corbalán-García S., Gómez-Fernández J.C., Biochim.Biophys. Acta, 2006, Vol. 1761, pp. 633-654.

40. House C., Kemp B.E., Science, 1987, Vol. 238, pp. 1726-1728.

33. Kohout S.C., Corbalan-Garcia S., GomezFernandez J.C., Falke J.J., Biochemistry, 2003, Vol. 42, No 5, pp. 1254-1265.

42. Ausili A., Corbalán-García S., GómezFernández J.C., Marsh D., Biochim. Biophys. Acta, 2011, Vol. 1808, pp. 684-695.

43. Liu Y., Witte S., Liu Y.C., Doyle M. et al., J. Biol. Chem., 2000, Vol. 275, pp. 3603-3609.

44. Chen C., Malkova S., Pingali S.V., Long F. et al., Biophys. J., 2009, Vol. 97, pp. 27942802.

45. Glushko A.A., Voronkov A.V., Chernikov M.V., Bioorganicheskaja khimija, 2014, Vol. 40, No 5, pp. 515-527.

46. Salmikangas P., Mykkanen O.M., Gronholm M., Heiska L. et al., Hum. Mol. Genet., 1999, Vol. 8, pp. 1329-1336.

47. Tong P., Khayat Z.A., Huang C., Patel N. etal., J. Clin. Invest., 2001, Vol. 108, pp. 371381.

48. Liu L.D., He A.B., Liu K.D., Li J. etal., Biokhimija, 2006, Vol. 71, No 7, pp. 869-875.

49. Hers I., Vincent E.E., Tavaré J.M., Cell Signal., 2011, Vol. 23, No 10, pp. 1515-1527.

50. Le Good J.A., Ziegler W.H., Parekh D.B., Alessi D.R. et al., Science, 1998, Vol. 281, pp. 2042-2045.

51. Orlov Yu.N., Biologicheskie membrany, 2015, Vol.32, No 3, pp. 151-167.

52. McLaughlin S., Murray D., Nature, 2005, Vol. 438, No 64, pp. 605-611.

53. Cho W., Stahelin R.V., Annu. Rev. Biophys. Biomol. Struct., 2005, Vol. 34, pp. 119151.

54. Seet L.F., Hong W., Biochim. Biophys. Acta, 2006, Vol. 1761, pp. 878-896.

55. Mayer B.J., Ren R., Clark K.L., Baltimore D., Cell., 1993, Vol. 73, No 4, pp. 629-630. 
DOI:10.1016/0092-8674(93)90244-K. PMID 8500161.

56. Haslam R.J., Koide H.B., Hemmings B.A., Nature, 1993, Vol. 363, No 6427, pp. 309-310. DOI:10.1038/363309B0. PMID 8497315.

57. Musacchio A., Gibson T., Rice P., Thompson J. et al., Trends in Biochemical Sciences, 1993, Vol. 18, No 9, pp. 343-348. DOI:10.1016/0968-0004(93)90071-T. PMID 8236453.

58. Gibson T.J, Hyvönen M., Musacchio A., Saraste M. et al., Trends in Biochemical Science, 1994, Vol. 19, No 9, pp. 349-353.

59. Wang D.S., Shaw G., Biochem. and Biophys. Research Communications, 1995, Vol. 217, No 2, pp. 608-615. DOI:10.1006/BBRC.1995.2818. 7503742 .

60. Wang D.S., Shaw R., Winkelmann J.C., Shaw G., Biochem. and Biophys. Research Communications, 1994, Vol. 203, No 1, pp. 2935. DOI:10.1006/BBRC.1994.2144. PMID 8074669.

61. Yao L., Kawakami Y., Kawakami T., Proceedings of the National Academy of Sciences of the USA, 1994, Vol. 91, No 19, pp. 9175-9179. DOI:10.1073/PNAS.91.19.9175. PMC 44770. PMID 7522330

Артюхов Валерий Григорьевич - професcop, зав. кафедрой биофизики и биотехнологии, д.б.н., Воронежский государственный университет, Воронеж

Башарина Ольга Владимировна - доцент кафедры биофизики и биотехнологии, к.б.н., Воронежский государственный университет, Воронеж
62. Di Nitto J.P., Lambright D.G., Biochim. Biophys. Acta, 2006, Vol. 1761, pp. 850-867.

63. Lemmon M.A., Biochem. Soc. Trans., 2004, Vol. 32, pp. 707-711.

64. Manning G., Whyte D.B., Martinez R., Hunter T. et al., Science, 2002, Vol. 298, pp. 1912-1934.

65. Korobko I.V., Korobko E.V., Kiselev S.L., Mol. Gen. Genet., 2000, Vol. 264, pp. 411-418.

66. Kalinichenko S.V., Korobko E.V., Korobko I.V., Biokhimiya, 2008, Vol. 73. No 3, pp. 342-348.

67. Spudich G., Chibalina M.V., Au J.S., Arden S.D. et al., Nat. Cell Biol., 2007, Vol. 9, No 2, pp. 176-183.

68. Herrig A., Janke M., Austermann J., Gerke V. et al., Biochemistry, 2006, Vol. 45, No 43, pp. 13025-13034.

69. Sanchez-Bautista S., Marin-Vicente C., Gomez-Fernandez J.C., Corbalan-Garcia S., J. Mol. Biol., 2006, Vol. 362, No 5, pp. 901-914.

70. Birkeland H.C., Stenmark H., Curr. Top. Microbiol. Immunol., 2004, Vol. 282, pp. 89115.

71. Yamauchi E., Nakatsu T., Matsubara M., Kato H. et al., Nature Struct. Biol., 2003, Vol. 10, pp. 226-231.

Artyukhov Valerij G. - prof., grand Ph.D (biology), head of the department of biophysics and biotechnology, Voronezh State University, Voronezh

Basharina Olga V. - Candidate of Biological Sciences, associate prof., department of biophysics and biotechnology, Voronezh State University, Voronezh, e-mail: bov-bio@yandex.ru 